\title{
The Training Mode and Teaching Method Reform of Full-Time Master of Engineering Practice and Innovation Ability
}

\author{
Jianfeng li; Qihui Zhao; Caihong Zhang; Lulu Hao \\ School of civil engineering, Xi Jing University \\ Xi'an 710123
}

\begin{abstract}
To improve the ability of practice and innovation is the core of the full-time Master of engineering training, but also test the training of master of engineering quality standards, and ensure the quality of the full-time Master of engineering training mainly depends on the scientific teaching training scheme and good professional practice base construction. According to the current situation of training full-time Master of engineering practice ability of the curriculum, teaching practice, research; establish a set of suitable for China's actual situation of the full-time Master of engineering practice ability training system.
\end{abstract}

Keywords-Full-time Master of Engineering; Practice and innovation ability; Culture system

\section{INTRODUCTION}

Master of engineering is a type of professional degree. Full-time Master's degree in engineering refers to obtaining the qualifications for studying in the country through the unified entrance examination of national graduate students, After full-time study in school, after graduation, can obtain a diploma and degree certificate of master of Engineering education. The master of Engineering in China started in 1997, and has experienced three stages of pilot training, scale development and quality improvement in [1]. At present, the full-time Master's degree in engineering covers 40 areas of empowerment and more than 200 training units. Master of engineering is a type of graduate student who is relative to academic master of engineering. [2], its practical, practical and professional characteristics, is a distinctive feature of full-time Master of engineering, it is more focused on the training for the enterprise and the production department has applied talents to solve practical problems, the emphasis is to apply professional theoretical knowledge into practice, for the application of engineering work.

The training of full-time Master of Engineering in foreign countries has not been strictly differentiated and studied in terms of full-time and part-time, In particular, there is less literature on the practical ability of full-time Master of Engineering postgraduates. In our country, Most of the existing research literatures focus on the cultivation of scientific research ability, but there is relatively little research on the training of Postgraduates' practical ability. Students practice and application, occupation of outstanding full-time Master of engineering research, how to strengthen the practice teaching in the training, improve their practice ability and innovation ability has become an urgent need to solve the problem.

\section{CURRENT SITUATION OF FULL-TIME ENGINEERING MASTER'S PRACTICAL ABILITY TRAINING}

\section{A. Lack of social cognition}

It is late and short time for the training of professional postgraduates. The society of graduate education is a general lack of awareness. Postgraduate admission score is low, excellent students lack of enthusiasm; two is the society of postgraduate recognition is low. Think academic postgraduate students basic theory, professional knowledge than postgraduate solid, practical knowledge, practical ability of graduate students are not necessarily stronger than graduate academic students to postgraduate employment obstacles.

\section{B. Congenital deficiency of training program}

The training program plays an important role in overall planning and guiding for the training of master of engineering. The shortcomings of the training program at the present stage are as follows:(1)it is made by the school unilaterally, and the participation of the enterprise is insufficient, especially in the training methods and curriculum system and the content of the teaching. (2)In the design of training methods and processes, the lack of enthusiasm and initiative to mobilize students and business mentors, students and corporate mentors are often passive acceptance.

\section{Lack of targeted curriculum system}

Since the implementation of the training system of postgraduate curriculum system, and some schools use academic graduate that set, did not form their own unique training curriculum system, the selection of teaching materials targeted is not strong, from teaching materials and engineering practice, with emphasis on theoretical calculation, the professional course teaching content is not intuitive, is suitable for the master postgraduate training textbook rare, postgraduate cultivation advantages, characteristics, innovation, quality and hinder the improvement of talent training industry. 


\section{Lack of cooperation between schools and enterprises}

Practical teaching is an important link in the training of postgraduates. At present, universities and cooperative enterprises are not closely linked with each other. Because colleges and universities are not closely related to enterprises, some cooperative enterprises are not enthusiastic enough, and schools lack high-quality practice relying on the platform, and the effect of practical links is difficult to guarantee.

\section{CONSTRUCTION OF PRACTICAL ABILITY TRAINING SYSTEM FOR FULL-TIME ENGINEERING POSTGRADUATES}

Aiming at the existing problems, In accordance with the spirit of "service special needs of the state personnel training program", spirit of service items, double tutors, binding joint training guidelines, training application, combined with high level engineering technology and management personnel, Fig. 1 is the master of our school full-time students engineering practice ability training system.

\section{A. Highlighting the practice links in curriculum setting}

1) Increase the content of practice curriculum system in the proportion of full-time Master of Engineering Research on the curriculum should be directed by actual application, strengthening the organic combination of theoretical teaching content should emphasize the theory and application of the curriculum, set up to adapt to the actual needs of the knowledge structure.

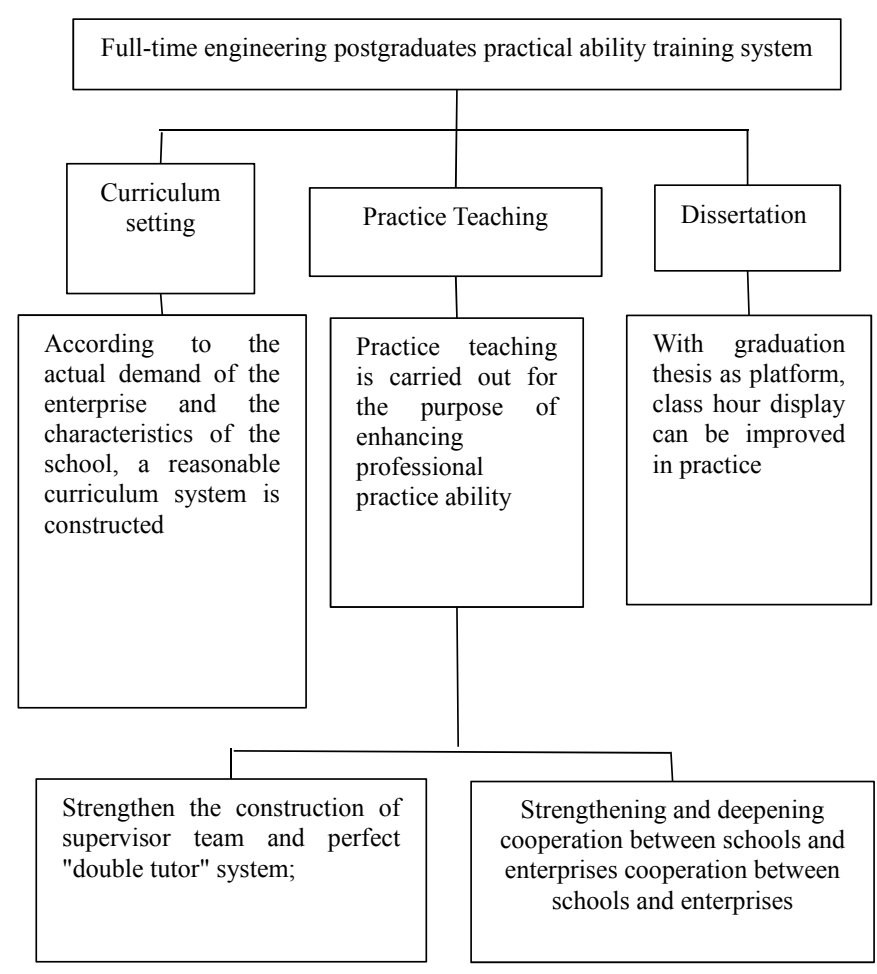

Fig. 1. full-time engineering master student practical ability training system

2) Implementation of the curriculum and occupation qualification relative access, the academic committee of the State Council pointed out that one of the principles of engineering graduate student is full-time development to meet the needs of society, strengthen the occupation oriented full-time engineering master education must be tightly combined with specific occupation field talent needs to gradually docking with the occupation certification exam, improve students' occupation ability.

3) Using the "flip class" teaching mode, the majority of full-time Master of Engineering Master's courses are taught mainly by teachers, and lack of seminars, such as teacher-student interaction or student-centered classroom teaching model. To give full play to student's exploration spirit and practical ability, we must adopt the flipped classroom teaching mode, the discussion teaching, case teaching, teaching mode of academic lectures and other courses, so that students become passive to accept knowledge learning.

\section{B. Establish an internship base both inside and outside the school, and perfect the management system}

The establishment of internal and external training base in Colleges and universities should use their own resources, through the establishment of specialized laboratories, set up a professional open experiment to provide a practical platform for the students to provide comprehensive practical ability training environment, to improve the students' practical ability.

Hire training work with rich practical experience of senior engineering and technical personnel and university teachers together to undertake full-time Master of engineering, senior engineer of the formation of teachers in Colleges and universities and enterprises to cultivation of Engineering Postgraduates pattern.

Improve the base management system, we must establish a strict review system, and resolutely put an end to re listing, light use phenomenon. The establishment of the base management organization shall be made up of the base units, the principal leaders and the dean of the college and the two sides shall jointly be responsible for the construction and routine management of the base.

\section{Degree thesis and enterprise practice are closely integrated}

Full-time engineering master degree training, to take the Ministry of education recommended "Curriculum Learning" + "professional practice" + "degree thesis" three paragraph training mode [3]. The topic of the thesis emphasizes application, development and practice, and examines the ability of graduate students to apply scientific theories, methods and techniques comprehensively to solve practical problems. The subjects supported by Graduation Theses of professional degree graduates should generally come from engineering practice, or have definite engineering background and application value.

Through professional practice, the problems of production, the thesis aiming at the problems, the major projects in the country, the construction industry enterprise joint research projects supported by the school and enterprise mentors to guide the work of this dissertation, and ultimately by the experts as the leading enterprises, quality control. 


\section{Apply professional knowledge to practice}

Practice base is an important part of realizing the training of professional degree graduates, and it is also an important platform to train practical ability of professional degree graduate students.

The connection of professional degree graduate education and professional qualification certification is the need of training postgraduates with professional degree, and also conducive to the employment of professional degree graduate students. Therefore, full-time Master of engineering graduate education must be closely integrated with specific needs in the field of professional talent, and gradually with the vocational certification examination docking, improve the students' professional ability.

Practical ability and creative ability is the core of postgraduate training. Through the construction of practice base, relying on professional and related scientific research projects and in the guidance of school and enterprise mentors training, graduate students can make full use of science and divergent thinking, using professional need freedom to carry out innovation activities, the innovative individual bold ideas applied to solve practical problems in the process of the competition. Which constantly sum up, refine, improve, enhance creative thinking, arouse the enthusiasm of innovation, from the surface to improve innovation ability and practice ability.

Graduate courses focus on teaching quality and heuristic teaching level, change teaching methods and teaching means, encourage the instructor to use advanced graduate teaching theory, actively use modern teaching methods to improve teaching quality.

\section{CONCLUSION}

On the basis of above analysis, we can draw the following conclusions:
Master of Engineering in China started in 1997, after the pilot training, the scale of development to enhance the quality of the three stages, the master of engineering is academic and master of Engineering relative a graduate type, practical application, and occupation of full-time Postgraduates of engineering characteristics of culture, it emphasizes is the use of professional theory knowledge into practice, for the application of Engineering work.

To study full-time Master of engineering students practice ability training status of research, found that China's society, lack of training programs congenitally deficient, lack of targeted curriculum system and the lack of cooperation on the project master cognitive presence.

In view of the above analysis, a full-time project master's practical ability training system is constructed. The main focus of the construction of the training system in practice, highlighting the curriculum in the establishment of internal and external practice base, improves the management system, thesis and enterprise practice and professional knowledge to practice.

\section{REFERENCES}

[1] Zhao Yanling, Xue Qingzhong, Liang Changguo. Construction of practical ability training system for full-time engineering postgraduates $[\mathrm{J}]$. Heilongjiang Education (higher education research and evaluation), 2016, (12): 55-57. (In Chinese)

[2] Ministry of education. Opinions on the training of full-time Master degree graduates, [Z]. Research and teaching, [2009]1, 2009-03-19. (In Chinese)

[3] Song Ping, Yang Lianmao, Zhen Liang, Ding Xuemei. Construction of practical ability training system for full-time engineering master degree [J]. Degree and graduate education, 2011, (03): 61-64. (In Chinese) 